Leszek Kania

Uniwersytet Przyrodniczo-Humanistyczny w Siedlcach e-mail: leszek.kania@uph.edu.pl telefon: +48256431517

DOI: 10.15290/mhi.2015.14.01.14

\title{
Sądy wojenne w Ludowym Wojsku Polskim (1943-1945)
}

\section{SUMMARY}

Polish People's Army Courts-martial in 1943-1945

Since its inception the communist forces' system of military justice had constituted a part of the system of subordinating entire front-line units to the communist rule, and the advancing Sovietisation of the Polish People's Army. The Soviet communists had their own experience in the fields of enforcing obedience and wide-scale infiltration, including that of the armed forces. Red Army, SMERSH and NKVD officers detached to the PPA and the security apparatus involved, introduced Soviet-inspired police terror and disciplinary tactics in the army, temporarily making use of pre-war symbolism and cynically referring to the tradition of the Second Polish Republic. The judicial practice of courts-martial was aimed at preparing the Polish army and war-weary population to accept the communist ideology, and for clearing the military of those discontented with post-Yalta reality.

Key words: Polish army, courts-martrial, system of military justice, desertion, capital punishment

Słowa kluczowe: armia polska, sądy wojenne, wojskowe prawo karne, kara śmierci, dezercja

\section{Organizacja sądownictwa}

Narodowy charakter Ludowego Wojska Polskiego (LWP) jest przedmiotem sporu badaczy ${ }^{1}$. Polskie Siły Zbrojne w Związku Socjalistycznych Republik Radzieckich (ZSRS) zostały zorganizowane na terytorium państwa, które nie utrzymywało stosunków dyplomatycznych z legalnym rządem polskim na uchodźstwie. W swojej podstawowej warstwie oficerowie i żołnierze Ludo-

1 Cz. Grzelak, H. Stańczyk, S. Zwoliński, Armia Berlinga i Żymierskiego, Warszawa 2002, s. 95-96. 
wego Wojska Polskiego składali się z osób wcześniej represjonowanych przez sowiecki aparat bezpieczeństwa, zaś kadra kierownicza składała się z oficerów Armii Czerwonej i dezerterów z Armii Polskiej na Wschodzie, którą gen. Władysław Anders w 1942 r. wyprowadził do Iranu². Związek Sowiecki od połowy 1941 r. był filarem koalicji antyhitlerowskiej. W LWP obowiązywał polski ceremoniał wojskowy, polski hymn narodowy, polskie mundury i język, polskie sztandary i godło (choć orzeł bez korony), przedwojenne modlitwy i nabożeństwa, polska musztra, dawne pieśni żołnierskie i duszpasterstwo ${ }^{3}$. Odmienności zaznaczyły się $\mathrm{w}$ działalności organów kontrwywiadu wojskowego (Zarządu Głównego Informacji Wojskowej WP), który faktycznie był częścią sowieckiego aparatu bezpieczeństwa oraz ściśle współpracującego z nim sądownictwa wojennego.

Początek dziejów służby sprawiedliwości $\mathrm{w}$ LWP jest związany $\mathrm{z}$ powstaniem w Sielcach nad Oką 1. Dywizji Piechoty (DP) im. T. Kościuszki Utworzono wówczas dywizyjny sąd polowy i prokuraturę. Elżbieta Romanowska w swoich badaniach podkreśla podległość prokuratur sądom wojen$n^{n}{ }^{5}$. W istocie sąd i prokuratura były organizacyjnie niezależne od siebie, przy czym, ewolucja wojskowego aparatu sprawiedliwości wyraźnie zmierzała $\mathrm{w}$ kierunku całkowitego rozdzielenia prokuratury od sądownictwa i powiązania organów prokuratury z aparatem bezpieczeństwa. We wrześniu 1944 r., w „Polsce Lubelskiej”, sądy wojskowe stały się posłusznym narzędziem wykonawczym rozbudowanego aparatu bezpieczeństwa. Ten zaś faktycznie podporządkował sobie prokuraturę i zgodnie $\mathrm{z}$ najgorszymi wzorami sowieckimi wykorzystywał ją do terroryzowania wojska i społeczeństwa. W lipcu 1943 r. etat dywizji na ogółem 838 stanowisk oficerskich przewidywał cztery etaty w sądownictwie wojennym (po dwa etaty na sąd polowy i prokuraturę) $)^{6}$. W sierpniu 1943 r. Państwowy Komitet Obrony ZSRS podjął decyzję o zorganizowaniu I. Korpusu Polskich Sił Zbrojnych. Na mocy rozkazu gen. bryg. Zygmunta Berlinga, dowódcy I. Korpusu PSZ, 1 września 1943 r. został utworzony korpu-

2 Zob. L. Kania, Polskie sądy wojskowe w Armii Polskiej gen. Władysława Andersa w ZSRS oraz na Bliskim i Środkowym Wschodzie (1941-1943), „Zeszyty Naukowe UPH w Siedlcach”, nr 100, Siedlce 2014.

3 Dodawanie przymiotnika "ludowe" lub używanie przez dziesięciolecia skrótu „LWP” nie było uzasadnione normatywnie, ale powszechnie przyjęło się dla odróżnienia PSZ utworzonych przez komunistyczny ośrodek władzy od PSZ na Zachodzie lub Wojska Polskiego z okresu międzywojnia.

4 Zob. B. Dzięcioł, Sądownictwo wojenne Ludowego Wojska Polskiego, „Wojskowy Przegląd Prawniczy” (dalej: WPP) 1978, nr 1.

5 E. Romanowska, Wojskowe prokuratury Polskich Kolei Państwowych w latach 1944-1989. Formalno-prawne podstawy działalności, „Przegląd Historyczno-Wojskowy” (dalej: PHW) 2011, nr 1, s. 97 i nast. Początkowo prokuratura wojskowa podlegała tylko administracyjnie sądom polowym, ale prerogatywy prokuratora w postępowaniu karnym i w zakresie ścigania przestępstw w zdecydowany sposób odbiegały od wzorca przedwojennego.

Ibidem. 
śny Sąd Polowy ${ }^{7}$. Zorganizował go ppłk Stefan Piekarski, który w końcu maja 1943 r. został przeniesiony z Armii Czerwonej do Wojska Polskiego ${ }^{8}$. Jego obowiązki związane z kierowaniem Sądem Polowym 1. DP przejął kpt. Leonard Azarkiewicz. Sąd Polowy I. Korpusu Polskiego PSZ na podstawie rozkazu dowódcy tego związku operacyjnego z 28 sierpnia 1943 r. miał pełnić rolę sądu II instancji jako sąd odwoławczy od orzeczeń dywizyjnych sądów polowych'.

Od jesieni 1943 r. wobec dynamicznej rozbudowy Ludowego Wojska Polskiego tworzono kolejne sądy polowe. $Z$ dniem 8 października 1943 r. rozpoczął działalność Sąd Polowy 2. DP (przewodniczący - kpt. Anatol Targuński). Od 5 stycznia 1944 r. prowadził działalność Sąd Polowy 3. DP (przewodniczący - kpt. Józef Łucewicz). W marcu 1944 r. nastąpiły poważne zmiany personalne w kierownictwie wojskowej służby sprawiedliwości. Na stanowisku przewodniczącego Sądu Polowego 1. Korpusu PSZ w ZSRR ppłk. Piekarskiego zastąpił delegowany z Armii Czerwonej płk Aleksander Tarnowski, a funkcję jego zastępcy objął ppłk Aleksander Michniewicz. Obaj oficerowie mieli aż do końca wojny kierować wojskową służbą sprawiedliwości. Jak można przypuszczać, ppłk Piekarski, mimo dyspozycyjności, nie sprostał intelektualnie na wyznaczonym stanowisku i został przesunięty do kierowania Sądem Polowym 3. DP, gdzie zastąpił krytykowanego za opieszałość w działaniu kpt. Targuńskiego. W kwietniu 1944 r. utworzono Sąd Polowy 4. DP (przewodniczący - por. Kazimierz Drohomirecki), a Sąd Polowy 1. Korpusu PSZ w ZSRR został przekształcony w Sąd Polowy 1. Armii Polskiej w ZSRR. W drugiej połowie lipca 1944 r. przystąpiono do organizowania sądów polowych kolejnych związków taktycznych w rejonie Żytomierza. Powstały wówczas Sąd Polowy 1. Korpusu Pancernego (przewodniczący - mjr Konstanty Lasota), Sąd Polowy 5. DP (przewodniczący - por. Marian Osowski), i Sąd Polowy 6. DP (przewodniczący por. Gotfryd Osowski). W połowie września 1944 r. etaty zajmowane przez płk. Aleksandra Tarnowskiego i płk. Aleksandra Michniewicza zostały podniesione do generalskich. Jednocześnie we wrześniu i październiku 1944 r. utworzono kolejne sądy polowe związków taktycznych wchodzących w skład 2. Armii Wojska Polskiego: Sąd Polowy 2. Armii WP (przewodniczący - ppłk. Stefan Piekarski), Sąd Polowy 7. DP (przewodniczący - por. Edmund Majchrzak), Sąd Polowy 8. DP (przewodniczący - por. Stanisław Mercik), Sąd Polowy 9. DP (przewodniczący - por. Eugeniusz Chomicki), Sąd Polowy 10. DP (przewodniczący - por. Edmund Majchrzak), Sąd Polowy 11. DP (przewodniczący por. Mieczysław Makarski), Sąd Polowy 2. Dywizji Artylerii (przewodniczący

Archiwum Służby Sprawiedliwości MON, sygn. 256/56/47, k. 2; B. Dzięcioł, op. cit., s. 21-22.

Zob. biogram płk. S. Piekarskiego [w:] K. Szwagrzyk, Zbrodnie w majestacie prawa 1944-1955, Warszawa 2000, s. 149 i nast.

9 B. Dzięcioł, Sąd Polowy 1 Korpusu Polskiego Polskich Sił Zbrojnych w ZSRR. Organizacja i działalność (cz. 1), WPP, 1980, nr 1, s. 14. 
- ppor. Bolesław Noskowski), Sąd Polowy 5. Dywizji Artylerii (przewodniczący - ppor. Józef Badecki). Utworzono także Sąd Polowy 3. Armii Wojska Polskiego (przewodniczący - mjr Marian Krupski), ale wobec rezygnacji z tworzenia tego związku operacyjnego sąd ten zlikwidowano ${ }^{10}$.

Przed wejściem Ludowego Wojska Polskiego na Podlasie i Lubelszczyznę coraz bardziej dotkliwy stawał się brak własnych kadr. Większość audytorów z Kozielska, Starobielska i Ostaszkowa wymordowano wiosną 1940 r., a pozostali przy życiu zginęli w czasie ewakuacji więzień NKWD po 22 czerwca $1941 \mathrm{r}$. lub szczęśliwie wyszli wraz z APW gen. Andersa do Iranu. Zmusiło to organizatorów 1. DP w połowie $1943 \mathrm{r}$. do wykorzystania oficerów sowieckich polskiego pochodzenia lub o polsko brzmiących nazwiskach. Wedle badań powojennych, na ogółem 5171 oficerów służących w PSZ w ZSRR 1 lipca 1944 r. tylko dziewiętnastu służyło w sądach i prokuraturach wojskowych LWP ${ }^{11}$. Mimo odczuwalnego niedoboru wykwalifikowanych prawników wojskowych, każda sformowana wielka jednostka (brygada, dywizja, korpus) wyruszyła na front $\mathrm{z}$ własnym sądem polowym. Sytuacja kadrowa radykalnie zmieniła się na korzyść po wkroczeniu Armii Czerwonej i oddziałów LWP na ziemie polskie. Przyjęto wówczas do sądownictwa wojennego LWP na zasadzie zaciągu ochotniczego lub poboru przedwojennych audytorów, prawników podziemnego wymiaru sprawiedliwości ZWZ-AK lub osoby z wykształceniem prawniczym. $W$ dalszym ciągu kierownicze stanowiska $\mathrm{W}$ aparacie sądowym LWP pełnili dawni oficerowie sowieccy. Brak prawników wojskowych o proweniencji komunistycznej zmusił płk. Tarnowskiego do wystąpienia do Naczelnego Dowódcy WP z projektem utworzenia Oficerskiej Szkoły Prawniczej. Sowiecki oficer, którego postawiono na czele sądownictwa Ludowego Wojska Polskiego argumentował swój projekt koniecznością "nasycenia kadr elementem ludowym, szczerze demokratycznym"12. Ogółem, od maja 1943 r. do końca wojny w maju 1945 r. w służbie sprawiedliwości Ludowego Wojska Polskiego pełniło służbę 48 oficerów Armii Czerwonej ${ }^{13}$. To ledwie jedna piąta stanu osobowego korpusu służby sprawiedliwości, jeśli pamiętać, że cały aparat GZI LWP składał się z oficerów delegowanych przez SMIERSZ i NKWD ${ }^{14}$. Z badań Andrzeja Wesołowskiego wynika, że 1 marca 1945 r.,

10 A. Wesołowski, W cieniu wojny i polityki. Sądownictwo Wojska Polskiego na froncie wschodnim w latach 1943-1945, Torun 2003, s. 162 i nast.

11 I. Błagowieszczański, Zarys formowania 1 Armii Wojska Polskiego, „Wojskowy Przegląd Historyczny” (dalej: WPH) 1959, nr 1, s. 45.

12 A. Wesołowski, op. cit., s. 153.

13 T. Gęsek, Z. Hofman, Pomoc ZSRR dla narodu polskiego w jego walce z Niemcami hitlerowskimi, [w:] 20 lat ludowego Wojska Polskiego, Warszawa 1967, s. 456. Zob. E. Nalepa, Oficerowie Armii Radzieckiej w Wojsku Polskim, Warszawa 1995.

14 V. Birstein, Smiersz - tajna broń Stalina. Sowiecki kontrwywiad wojskowy podczas II wojny światowej, Kraków 2013, s. 408. 
na ogółem 416 etatów w wojskowej służbie sprawiedliwości LWP, objętych było jedynie 265 (67,3\%). Do końca wojny pozostało obsadzonych 151 stanowisk oficerskich w sądownictwie wojskowym ${ }^{15}$. Braki kadrowe w korpusie oficerskim po masakrach 1940 r. i ewakuacji PSZ w ZSRR do Iranu wystąpiły $\mathrm{w}$ pozostałych rodzajach broni i służb. $\mathrm{Z}$ tego powodu nie mogło się rozwinąć m.in. lotnictwo wojskowe ${ }^{16}$.

Zasadnicze zmiany $\mathrm{w}$ sądownictwie wojennym nastąpiły na przełomie sierpnia i września 1944 r. Rozkazem Naczelnego Dowódcy WP nr 15 datowanym 2 września 1944 r. utworzono Wydział Sądownictwa Wojennego na szczeblu NDWP, Najwyższy Sąd Wojskowy i powołano Naczelnego Prokuratora Wojskowego ${ }^{17}$. W ostatnich dniach sierpnia 1944 r. rozpoczęły funkcjonowanie: Wojskowy Sąd Garnizonowy w Lublinie (przewodniczący - ppłk Konstanty Krukowski), Wojskowy Sąd Garnizonowy w Białymstoku (przewodniczący - mjr Bronisław Rakowski), Wojskowy Sąd Garnizonowy w Rzeszowie (przewodniczący - ppor. Władysław Garnowski). W ostatnich dniach listopada 1944 r. rozpoczął funkcjonowanie Sąd Wojskowy Polskich Kolei Państwowych (PKP - przewodniczący - mjr Aleksander Tomaszewski) ${ }^{18}$. Naczelny Dowódca WP rozkazem nr 72/Org. z 25 listopada 1944 r. zatwierdził etat Wojskowej Prokuratury PKP oraz etat ekspozytury prokuratury przy każdej z trzech Dyrekcji Okręgowych Polskich Kolei Państwowych. Trudności kadrowe pozwoliły w grudniu 1944 r. zorganizować jedynie Sąd Wojskowy i Prokuraturę Wojskową PKP. Na stanowisko szefa Prokuratury Wojskowej PKP został wyznaczony mir Jakub Prokopowicz z prokuratury 2. Armii LWP ${ }^{19}$. Struktura organizacyjna organów prokuratorskich $\mathrm{w}$ czasie wojny ostatecznie została ustalona rozkazem Naczelnego Dowódcy WP nr 42 z 17 marca 1945 r. Struktura organizacyjna wojskowych prokuratur PKP przedstawiała się następująco: Ekspozytura prokuratury wojskowej PKP przy DOKP w Krakowie (kpt. Bronisław Tomaszewski), Ekspozytura Prokuratury Wojskowej PKP przy DOKP w Białymstoku (oficer śledczy kpr. pchor. Adam Błażek), z tym, że prokuratura nie podjęła działalności do końca wojny, Ekspozytura Prokuratury Wojskowej PKP

15 A. Wesołowski, op. cit., s. 141.

16 E. Pawłowski, Ludowe Wojsko Polskie w końcowym okresie II wojny światowej, WPH 1987, nr 2, s. 4 i nast.

17 B. Dzięcioł, Sądownictwo wojenne..., op. cit., s. 24 i nast.; idem, Działalność Najwyższego Sądu Wojskowego w 1945 roku, WPP 1977, nr 1, s. 26-27.

18 E. Romanowska, op. cit., s. 111. Zob. też M. Zaborski, Ustrój sądów wojskowych w Polsce w latach 1944-1955, Lublin 2005, s. 220-221; T. Karpiński, Wydziat Zamiejscowy Wojskowego Sądu Polskich Kolei Państwowych w Poznaniu (1947-1949), WPP 2013, nr 2.

19 Według badań T. Karpińskiego na stanowiska podprokuratorów i oficerów śledczych Prokuratury Wojskowej PKP zostali wyznaczeni: kpt. Bronisław Tomaszewski, por. Leon Kanel, por. Jan Kuczyński, ppor. Jerzy Pokorny, ppor. Jerzy Waligórski, chor. Józef Jakimiński, chór. Mieczysław Nesterowicz, chór. Stefan Gąsiorowski. 
przy DOKP w Lublinie (por. Leon Kanel), Ekspozytura Prokuratury Wojskowej PKP przy DOKP w Olsztynie (chor. Wacław Dawidowicz), Ekspozytura Prokuratury Wojskowej PKP przy DOKP w Łodzi (ppor. Henryk Monkiewicz), Ekspozytura Prokuratury Wojskowej PKP przy DOKP w Gdańsku (ppor. Franciszek Marszałek), Ekspozytura Prokuratury Wojskowej PKP przy DOKP w Poznaniu (ppor. Stanisław Wągrowski), Ekspozytura Prokuratury Wojskowej PKP przy DOKP w Katowicach (podprokurator - szer. z cenzusem Stefan Zieliński). Do końca wojny nie zorganizowano ekspozytur przy DOKP w Szczecinie i Wrocławiu.

Po wyzwoleniu stolicy kierownicze władze wojskowej służby sprawiedliwości zostały przeniesione do Piastowa pod Warszawą. W miarę postępów ofensywy styczniowej i przesuwania linii frontu na zachód pełnomocnicy Rządu Tymczasowego RP przejmowali pod ochroną sowieckiego aparatu bezpieczeństwa władzę polityczną na obszarach wyzwolonych. Dało to również asumpt do tworzenia terytorialnych sądów wojskowych. Na początku stycznia 1945 r. utworzono Wojskowy Sąd Warszawskiego Garnizonu (prezes - mjr Marian Krupski), Wojskowe Sądy Garnizonowe w Chełmie Lubelskim (prezes mjr Kazimierz Nowosielski), Przemyślu (prezes - mjr Jan Krzechowicz), Siedlcach (prezes - mjr Bolesław Zwinklewicz). W końcu stycznia utworzono Wojskowe Sądy Garnizonowe w Łodzi (prezes - mjr Marian Osowski), Krakowie (prezes - mjr Leonard Rodziewicz) oraz Katowicach (prezes - por. Władysław Nitka), a w lutym w Krakowie, Łodzi, Toruniu i Poznaniu ${ }^{20}$. Na początku lutego 1945 r. utworzono siedem Wojskowych Sądów Okręgowych (WSO). Niektóre z nich powstały na bazie istniejących już Wojskowych Sądów Garnizonowych. W ten sposób utworzono wówczas WSO w Warszawie (prezes - mjr Piotr Parzeniecki), WSO w Lublinie (prezes - ppłk Konstanty Krukowski), WSO w Łodzi (prezes - mjr Marian Osowski), WSO w Krakowie (prezes - ppłk Bronisław Krakowski), WSO w Poznaniu (prezes - mjr Władysław Garnowski), WSO w Toruniu (prezes - mjr Józef Dziowgo), WSO w Gdańsku (prezes - mjr Jan Komorowski) ${ }^{21}$.

\section{2. Źródła prawa}

Zerwanie z prawno-politycznym porządkiem II Rzeczypospolitej zmusił komunistyczny ośrodek władzy do poszukiwania własnych regulacji prawnokarnych na potrzeby sądownictwa wojennego ${ }^{22}$. O ile zasady działania są- 
downictwa oparto początkowo na kodeksie wojskowego postępowania karnego z 1936 r., o tyle przedwojenny kodeks karny wojskowy (k.k.w.) z 1932 r. zdecydowanie odrzucono ${ }^{23}$. W jego miejsce Prezydium Zarządu Głównego Związku Patriotów Polskich (ZPP) uchwaliło w lipcu 1943 r. wprowadzenie w życie nowego kodeksu karnego wojskowego na potrzeby Polskich Sił Zbrojnych organizowanych na terenie ZSRS ${ }^{24}$. Kodeks ten, wzorowany na kodeksie wojskowym RFSRR z 1926 r., raził prymitywizmem instytucji prawnokarnych, niechlujnie sformułowanymi dyspozycjami i szeregiem dziwolągów językowych. Niektóre przetłumaczono dosłownie z języka rosyjskiego. Wszystko wskazuje na to, że projekt opracował ppłk Stefan Piekarski, oficer sowiecki, który nie znał przedwojennego ustawodawstwa wojskowego. Nie dysponował zresztą ani jednym egzemplarzem k.k.w. z 1932 r. Kodeks karny wojskowy z 1943 r. wiernie oddawał realia społeczne w ZSRS w szczytowym okresie zmagań wojennych. Dla przykładu, przepis art. 11 jako okoliczności łagodzące traktował popełnienie przestępstwa „pod wpływem głodu” lub „wskutek ciemnoty”. Ewidentne było tu oddziaływanie prawa karnego ZSRS, które „polityzowało” w możliwie każdej sytuacji czyn zabroniony i potencjalnego sprawcę przestępstwa ${ }^{25}$. Uzupełnieniem tej regulacji, bo trudno kodeks nazwać inaczej, był Cyrkularz nr 2 dowódcy 1. Korpusu PSZ w ZSRS z 20 września 1943 r., który zawierał przepisy ustrojowo-procesowe dla sądów polowych. Tenże akt normatywny oraz wprowadzony w życie 26 listopada 1943 r. „Kodeks postępowania karnego PSZ" określiły nowy model prokuratury wojskowej. Odtąd prokuratorzy,

23 A. Lityński, O ustanowieniu i upadku tzw. Kodeksu wojskowego Polskich Sit Zbrojnych w ZSRR, "Z dziejów prawa. Prace Naukowe UŚl.", nr 2455, cz. 8, Katowice 2006; idem, Początki prawa komunistycznego w Polsce. Prawo karne wojskowe przed wrześniem 1944 r., „Pamięć i Sprawiedliwość. Biuletyn Głównej Komisji Badania Zbrodni przeciwko Narodowi Polskiemu, Warszawa 1996; idem, Początki służby sprawiedliwości w Polskich Siłach Zbrojnych w ZSRR (1943 r.), [w:] Dawne prawo i myśl prawnicza. Prace historyczno-prawne poświęcone pamięci Wojciecha Marii Bartla, red. J. Malec, W. Uruszczak, Kraków 1995; idem : Historia prawa radzieckiego 1917-1991. Krótki kurs, „Miscellanea Historico-Iuridica” 2005, t. III, idem, Ze studiów nad początkami wojskowego prawa karnego PRL, „Problemy Prawa Karnego", t. 21, red. K. Marszał, Katowice 1995; idem, O prawie i sądach początków Polski Ludowej, Białystok 1999; idem, Rok 1943 w Polskich Siłach Zbrojnych w ZSRR, [w:] Prace Wydziału Prawa i Administracji UAM, t. 1: Historia prawa - historia kultury. Liber Memorialis Vitoldo Maisel dedicatus, red. E. Borkowska-Bagieńska, H. Olszewski, Poznań 1994; idem, Historia prawa Polski Ludowej, Warszawa 2007; idem, Wyrok na "kodeks" PSZ w ZSRR, „Z dziejów prawa. Prace Naukowe UŚl.", nr 2455, cz. 8, Katowice 2006.

O genezie kodeksu PSZ w ZSRS zob. A. Lityński, O ustanowieniu i upadku..., s. 203; idem, Wyrok na ",kodeks" PSZ w ZSRR, s. 224-231; idem, O prawie i sq̨dach początków Polski Ludowej, s. 20 i nast.; idem, Historia prawa Polski Ludowej, s. 109 i nast.; idem, Rok 1943 w Polskich Siłach Zbrojnych..., s. 409 i nast.; idem, Początki służby sprawiedliwości..., op. cit., s. 237 i nast.; S. Guzy, Zapomniana uchwała, WPP 1963, numer specjalny, s. 62. A. Lityński słusznie zauważył, że w momencie decydowania o prawnym kształcie sądownictwa wojskowego przez ZG ZPP „Polskie Siły Zbrojne” składały się ledwie $\mathrm{z}$ jednej dywizji w fazie jej organizacji. 
oprócz tradycyjnych funkcji sądowych, mieli odpowiadać na profilaktykę przestępczości, kształtowanie zasad dyscypliny w procesie wychowawczym oraz za nadzór nad przestrzeganiem prawa. Nowe zasady funkcjonowania prokuratury ostatecznie przypieczętował nowy k.p.k. w PSZ w ZSRS, który zlikwidował instytucję sędziego śledczego i pozbawił sąd jakiejkolwiek kontroli nad postępowaniem przygotowawczym.

Kompromitujący poziom legislacyjny kodeksu karnego wojskowego z 1943 r. wymógł na dowództwie PSZ w ZSRS i kierownictwie ZPP konieczność uporządkowania wojskowego prawa sądowego. Na początku kwietnia 1944 r. została powołana pięcioosobowa „Komisja Kodyfikacyjna” w celu opracowania projektu kodeksu karnego wojskowego, prawa o ustroju sądów wojskowych oraz kodeksu wojskowego postępowania karnego. Na jej czele stanął zastępca dowódcy 1. Armii LWP gen. bryg. Aleksander Zawadzki. W porównaniu z kodeksem przyjętym w lipcu 1943 r. nastąpiła radykalna zmiana na korzyść. Nowy projekt k.k.w. wypracowali oficerowie, a nie politrucy skupieni w Związku Patriotów Polskich ${ }^{26}$. Mimo oczekiwań rozkazodawców na szybkie przeprowadzenie prac projektowych droga do przyjęcia nowego k.k.w. zaczęła się wydłużać. Do pierwszej wersji zgłosili poprawki sędziowie i prokuratorzy sądów polowych ${ }^{27}$. Polski Komitet Wyzwolenia Narodowego (PKWN) jednomyślnie zaaprobował projekt kodeksu karnego wojskowego, który przekazano Prezydium Krajowej Rady Narodowej (KRN) do zatwierdzenia. Ostatecznie 23 września 1944 r. KRN zatwierdziła decyzję PKWN i nakazała skierowanie Kodeksu karnego Wojska Polskiego do publikacji w Dzienniku Ustaw ${ }^{28}$. Kodeks karny Wojska Polskiego zastąpił kodeks lipcowy z 1943 r.

W porównaniu z kodeksem z 1943 r. nowy k.k.w. stał na nieporównywalnie wyższym poziomie legislacyjnym, gdyż w części szczególnej wzorował się na k.k.w. z 1932 r. To zapewniło komunikatywność i syntetyczność przekazu ${ }^{29}$. Poszczególne dyspozycje przestępstw wojskowych uległy na tyle modyfikacji,$$
\text { spectin }
$$
1986 , nr 4, s. 126 i nast; A. Lityński, Ze studiów nad początkami wojskowego prawa karnego PRL, [w:] Problemy prawa karnego, red. K. Marszał, t. 21, Katowice 1995, s. 12-20; idem, Początki prawa komunistycznego w Polsce. Prawo karne wojskowe przed wrześniem 1944 r., [w]: „Pamięć i Sprawiedliwość", t. 39, Warszawa 1996, s. 77 i nast.; idem, O prawie i sądach początków Polski Ludowej, Białystok 1999, s. 25-33; M. Muszkat, Podstawowe zasady Kodeksu Karnego Wojska Polskiego, WPP 1945, nr 1, s. 16 i nast.; J. Muszyński, Polityczno-prawne aspekty tworzenia Ludowego Wojska Polskiego w latach 1943-1945, „Państwo i Prawo” 1973, nr 10; idem, Jeszcze raz w sprawie kodeksu wojskowego Polskich Sit Zbrojnych w ZSRR z 1943 r. i kodeksu karnego wojskowego z dnia 30 maja 1944 r., WPP 1965, nr 3, s. 353 i nast. W. Sieracki, Rozwój wojskowego prawa karnego (materialnego) w latach 1943-1963, WPP 1963, numer
specjalny, s. 68 i nast.; E. Bandosz, Rozwój wojskowego prawa karnego w latach 1943-1945, WPH
} 
że ochronę prawnokarną rozciągnięto na żołnierzy Armii Czerwonej oraz życie i zdrowie „przedstawicieli państwa”. Niektóre z przestępstw, które chroniły wierność żołnierską pozwalały na represjonowanie żołnierzy podziemia niepodległościowego za odmowę wstąpienia do „armii Berlinga” ${ }^{30}$.

Dekretem PKWN z 24 sierpnia 1944 r. zdelegalizowano wszystkie podziemne organizacje niepodległościowe, przy czym, obiecywano zachowanie w LWP stopni wojskowych uzyskanych w okresie służby w tajnych organizacjach niepodległościowych. Reguła ta nie dotyczyła jednak formacji Narodowych Sił Zbrojnych. W ten sposób ruch narodowy i NSZ jako jego zbrojne ramię nowe władze uznały za organizację faszystowską ${ }^{31}$. Milowym krokiem we wprowadzeniu powszechnego terroru, w którym znaczącą rolę odegrało sądownictwo LWP, były dwa dekrety PKWN: dekret z 31 sierpnia 1944 r. O wymiarze kary dla faszystwowsko-hitlerowskich zbrodniarzy winnych zabójstw i znęcania się nad ludnością cywilną i jeńcami oraz zdrajców Narodu Polskiego i dekret z 30 października 1944 r. O ochronie państwa. Postępowanie w sprawach objętych dekretami przekazano sądom wojskowym, w których materializowały się postępowania wobec przeciwników władzy ludowej. Oba akty normatywne zawierały drakońskie kary i posłużyły komunistom do represjonowania swoich przeciwników politycznych ${ }^{32}$.

30 Część żołnierzy AK, zwłaszcza z polskich Kresów Wschodnich, schroniła się w LWP przed prześladowaniami NKWD pod zmienionymi nazwiskami i zatajeniu stopni wojskowych. Niektórym oficerom i żołnierzom AK udało się umknąć pogoni sowieckich służb specjalnych, zalegendować w oddziałach LWP pod bokiem Informacji Wojskowej i uniknąć identyfikacji. Przykładem są burzliwe losy ppłk. dypl. Aleksandra Klotza, przedwojennego dyplomaty i oficera polskiego wywiadu. W 1940 r. wraz z Wandą Ptaszek w ciągu roku przemierzył całe terytorium Związku Sowieckiego od Lwowa po Daleki Wschód w celu ustalenia losów deportowanej w głąb tego kraju polskiej ludności cywilnej i ustalenia miejsca pobytu gen. M. Karaszewicza-Tokarzewskiego. Dalsze lata wojny spędził we Lwowie, gdzie kierował kontrwywiadem Obszaru Lwowskiego ZWZ-AK. W sierpniu 1944 r. ppłk Aleksander Klotz podając się za lek. med. Jana Baranowskiego wstąpił do 2. Armii LWP, gdzie mimo braku wykształcenia medycznego kierował szpitalami i ściśle współpracował z gen. Świerczewskim. W 1946 r. ppłk Klotz zdezerterował z LWP i przedostał się na Zachód. Po rozwiązaniu PSZ na Zachodzie współpracował z brytyjskim wywiadem jako ekspert od spraw sowieckich. Zmarł naturalną śmiercią w Australii w 1976 r.

Pełny tekst Dekretu PKWN [w:] Dzienniku Urzędowym RP Nr 3, poz. 12 z 1944 r.

Izba Wojskowa SN wyrokiem z 19.06.2001 r. (WKN 13/01) orzekła, że k.k.w. PSZ z 1943 r. w ZSRS nie miał mocy obowiązującej prawa karnego, gdyż został wydany przez organ nieposiadający legitymacji do stanowienia przepisów rangi kodeksowej oraz w czasie obowiązywania k.k.w. z 1932 r., a skazanie na podstawie przepisów k.k.w. PSZ z 1943 r. w ZSRS stanowi rażące naruszenie prawa i może być podstawą do wniesienia kasacji. A. Lityński zwrócił uwagę na to, że wyrok ten odbiega od praktyki orzeczniczej Sądu Najwyższego i Trybunału Konstytucyjnego zgodnie stojących na stanowisku obowiązywania prawa ustanowionego w PRL. A. Lityński, Z problematyki legalności aktów prawnych Polski Ludowej. W związku z orzeczeniem Izby Wojskowej Sądu Najwyższego z 19 czerwca 2001 r. (WKN 13/01), „Studia z Dziejów Państwa i Prawa Polskiego” 2006, IX, cz. 2, s. 453 i nast. 


\section{Praktyka sądowa}

Pierwszy okres tworzenia Ludowego Wojska Polskiego cechował zaskakująco niski stan przestępczości. W ciągu całego drugiego półrocza 1943 r. Sąd Polowy 1. Korpusu PSZ w ZSRS rozpoznał łącznie jedynie 45 spraw karnych przeciwko 58 oficerom i żołnierzom. Uznano winę 49 podsądnych i spośród nich skazano tylko 3 żołnierzy na karę śmierci, a pozostałych na kary pozbawienia wolności. Wykonanie większości z tych kar odroczono zresztą do końca wojny. Nieliczni, wobec których zwierzchnicy sądowo-karni utrzymali wymierzone kary sądowe zostali osadzeni w Zakładzie Karnym w Riazaniu. Tylko jeden żołnierz został rozstrzelany za zabójstwo kolegi ${ }^{33}$. To doprawdy niewiele jak na 32,5 tys. ludzi zdemoralizowanych ponadtrzyletnią gehenną sowieckich obozów pracy, wysiedleń i pogardy wobec uprzednio wyznawanych wartości.

Sądy polowe LWP zlokalizowane przy sztabach dywizji i armii, po przesunięciu linii frontu nad Wisłę, zostały natychmiast włączone w machinę terroryzowania społeczeństwa polskiego. Władza tzw. Polskiego Komitetu Wyzwolenia Narodowego oparta wyłącznie na sprawności sowieckiego aparatu bezpieczeństwa i dywizjach Armii Czerwonej zrazu napotkała na zorganizowany opór społeczny. Na przełomie lat 1944/1945 na zapleczu sowieckich garnizonów, komendantur wojennych, terenowych komórek NKWD, MBP i MO funkcjonowało ok. 160 oddziałów partyzanckich. Dowódcy antykomunistycznego podziemia zbrojnego tylko od wiosny do jesieni 1945 r. zdobyli się na spektakularny wysiłek $\mathrm{w}$ postaci ataków na kilkadziesiąt całkowicie kontrolowanych przez NKWD i MBP większych miast (np. Lublin, Radom, Białystok) i miasteczek (np. Miechów, Kozienice, Pabianice, Radomsko, Biała Podlaska, Biłgoraj). Akcje te, oprócz osiągania efektów psychologicznych, przyniosły uwolnienie z więzień i obozów specjalnych kilkuset żołnierzy i działaczy podziemia niepodległościowego ${ }^{34}$. Rozbito $\mathrm{w}$ tym czasie trzy obozy specjalne NKWD w Piotrkowie, Nowinach i Rembertowie, w których więziono żołnierzy AK przed ich wywiezieniem w głąb Związku Sowieckiego. Z kolei, w Błudku śmiałym atakiem zlikwidowano całą ochronę tego obozu, odbito i uwolniono kilkuset więźniów, po czym rozstrzelano pięciu oficerów NKWD stanowiących jego sowiecką komendę ${ }^{35}$.

Polski Komitet Wyzwolenia Narodowego zainstalowany przez sowieckie służby specjalne na Lubelszczyźnie jako namiastka rządu, przed wylotem z Moskwy do Lublina podpisał porozumienie, na mocy którego zrzekł się na rzecz Związku Sowieckiego jurysdykcji wobec osób, które dopuszczą się

B. Dzięcioł, Sąd Polowy 1. Korpusu PSZ..., s. 20.

Armia Krajowa. Szkice z dziejów Sił Zbrojnych Polskiego Państwa Podziemnego, red. K. Komorowski, Warszawa 2001, s. 339.

Relacja Mariana Rozwalki złożona 12 stycznia 1990 roku w Lesznie - zbiory autora. 
przestępstw popełnionych $w$ strefie operacji wojennych prowadzonych przez oddziały Armii Czerwonej36. Uchwałą Państwowego Komitetu Obrony ZSRS z 20 lutego 1945 r. określono szerokość pasa przyfrontowego na 60 do $100 \mathrm{~km}$. W rezultacie, "Operacyjno-Czekistowskie organy i wojska NKWD” hulały na polskich ziemiach bez przeszkód dokonując planowych mordów, aresztowań i wywózek w sposób niekontrolowany nawet przez polskich komunistów. Na podstawie art. 7 tegoż „porozumienia” ratyfikowanego następnie przez KRN przekazano tysiące obywateli polskich pod właściwość sowieckich trybunałów specjalnych, które zasądzały zwykle na śmierć lub wieloletnie kary łagrów ${ }^{37}$. Formalnie na podstawie tego właśnie przepisu porwano i wywieziono do Moskwy przywódców Polski Podziemnej. Obywatele polscy skazani przez sowieckie specjalne trybunały wojskowe mogli ubiegać się o wznowienie postępowania, apelację lub ułaskawienie jedynie $\mathrm{w}$ trybie przewidzianym przez sowiecką procedurę wojskową. Wszelkie prośby i podania o wzruszenie zapadłych orzeczeń wnoszone do organów wymiaru sprawiedliwości „Polski Lubelskiej” były pozostawiane bez nadania im dalszego biegu ${ }^{38}$.

Na podstawie dekretów z początkowego okresu istnienia PKWN dopuszczono się kilku tysięcy mordów sądowych na działaczach niepodległościowych i żołnierzach antykomunistycznego podziemia zbrojnego. Wystarczy dodać, że na podstawie art. 1 dekretu $\mathrm{O}$ wymiarze kary dla faszystwowsko-hitlerowskich zbrodniarzy... skazano w sfingowanym procesie na karę śmierci w $1952 \mathrm{r}$. gen. bryg. Augusta Fieldorfa - „Nila”, szefa Kierownictwa Dywersji (Kedywu) Komendy Głównej Armii Krajowej. Nie trzeba dodawać, że w obozach NKWD, w komendanturach wojennych, siedzibach MBP i podczas akcji pacyfikacyjnych zamordowano bez sądu tysiące żołnierzy i działaczy podziemia niepodległościowego. W siedzibach MBP i Głównego Zarządu Informacji WP główną rolę w eksterminacji żołnierzy i działaczy podziemia niepodległościowego odgrywali doradcy sowieccy. Do końca grudnia 1944 r. w więzieniach, obozach specjalnych NKWD i innych miejscach straceń zamordowano bez wyroków sądowych kilka tysięcy żołnierzy i działaczy podziemia. Co najmniej drugie tyle zginęło $w$ obławach i zasadzkach oddziałów NKWD, MBP i KBW. W Skrobowie k. Lubartowa w listopadzie 1944 r. utworzono obóz specjalny GZI LWP kontrolowany przez oficerów NKWD. W nieludzkich warunkach przetrzymywano tam kilkuset żołnierzy LWP przybyłych z AK i innych niekomunistycznych formacji partyzanckich, których wytypowano jako ludzi niebezpiecznych dla "demokratycznego Państwa Polskiego". Uwięzionych pod-

36 A. Lityński, Od Rzeczypospolitej Szlacheckiej do Rzeczypospolitej Ludowej, s. 147. Zob. idem, O prawie i sądach początków Polski Ludowej, Białystok 1999.

37 Według badaczy epopei poakowskiego podziemia w łagrach osadzono ok. 15-17 tys. żołnierzy AK. Zob. I. Caban, Polacy internowani w ZSRR w latach 1944-1947, Lublin 1990, s. 7.

38 A. Wesołowski, op. cit., s. 149. 
dawano tam wyszukanym torturom i rozstrzeliwano bez sądu wedle uznania enkawudzistów ${ }^{39}$. Z kolei, w Kąkolewnicy na Lubelszczyźnie utworzono obóz karny dla oficerów i żołnierzy LWP podejrzanych o działalność antykomunistyczną. Oprócz oprawców z GZI WP i NKWD na miejscu urzędował Sąd Polowy 2. Armii LWP (przewodniczący - ppłk. Stefan Piekarski, sędziowie: kpt. Marian Bartoń, kpt. Aleksander Tomaszewski, kpt. Marcin Dancyg, por. Władysław Sobiech, por. Tadeusz Małecki). Sąd ten skazał co najmniej 144 żołnierzy, przy czym wobec 63 osób wydano karę śmierci. Skazanych rozstrzelano w kąkolewickich lasach. Oblicza się, że zamordowano tam łącznie od 1.500 do 1.800 osób $^{40}$.

Podstawą uruchomienia represji wobec żołnierzy AK była dyrektywa J. Stalina skierowana do dowódców sowieckich frontów z 1 sierpnia 1944 r., która nakazywała natychmiastowe rozbrojenie Armii Krajowej pod groźbą odpowiedzialności karnej według przepisów sowieckiego prawa wojennego. Oprócz tysięcy czerwonoarmistów i wyspecjalizowanych w zwalczaniu podziemia oddziałów NKWD i SMIERSZ-u, dowództwo LWP rzuciło przeciwko oddziałom antykomunistycznego podziemia w szczytowym okresie wojny antypartyzanckiej, czyli od czerwca 1945 do lipca 1947 r., 50 pułków piechoty, 16 samodzielnych batalionów KBW, 14 kompanii specjalnych, eskadrę samolotów, brygadę pancerną i dywizjon artylerii ${ }^{41}$. Liczebność tylko Wojsk Wewnętrznych NKWD odpowiadała sile siedmiu dywizji piechoty. W latach 1944-1945 terytorium Polski w nowych granicach od Bugu do Odry pokrywała sieć 319 sowieckich komendantur wojennych. Do akcji bojowych przeciwko polskiemu podziemiu używano sowieckich i polskich jednostek frontowych. Organa NKWD posiadały $\mathrm{w}$ terenie własne źródła informacyjne niezależnie od agentury posiadanej przez UB i GZI WP, własne więzienia i miejsca kaźni, do których nie dopuszczano nawet polskich komunistycznych popleczników. Żołnierze AK i NSZ podlegali losowej eksterminacji wedle swobodnego uznania sowieckich funkcjonariuszy NKWD i rodzimej bezpieki, a rodziny partyzantów i działaczy podziemia były aresztowane i wywożone do łagrów położonych na terenie Związku Sowieckiego. Wystarczyła przynależność do AK, podejrzenie lub donos, żeby trafić do katowni Informacji Wojskowej. Eliminowanie podejrzanych o kontynuowanie działalności podziemnej w szeregach Ludowego Wojska Polskiego odbywało się bez udziału prokuratorów i sądów wojskowych. Lasy kąkolewnickie, katownia UB na Zamku Lubelskim, w gmachu NKWD na ul. Chopina w Lublinie i wielu podobnych im miejscach kaźni

39 J. Poksiński, Obóz w Skrobowie w dokumentach (1946-1945), Dokumenty i Materiały. Archiwum Polski Podziemnej 1939-1956, nr 2, 1994, s. 157-202; Cz. Grzelak, Bez możliwości wyboru, s. 59.

41 Zob. Wykaz jednostek użytych do zwalczania bandytyzmu - Załącznik nr 1 do opracowania Sztabu Generalnego LWP nr 21/Sztab z 2 kwietnia 1975 r. 
kryją szczątki pomordowanych żołnierzy 2 . Armii LWP ${ }^{42}$. Równolegle trwało polowanie na partyzantów i sprzyjającą im ludność w terenie. Tylko z powiatu Sokołów Podlaski wywieziono w latach 1944-1945 do łagrów w głębi Związku Sowieckiego 2,5 tys. osób podejrzanych o współpracę z AK i NSZ ${ }^{43}$. W lipcu 1945 roku 62. Dywizja NKWD wraz z oddziałami Armii Czerwonej i jednostkami LWP przeprowadziła w rejonie Augustowa gigantyczną obławę na żołnierzy podziemia niepodległościowego i wspierających ich mieszkańców Suwalszczyzny. Z aresztowanych wówczas 7 tys. osób cywilnych odizolowano grupę 592 mieszkańców Suwalszczyzny, wobec których NKWD i UB posiadało informacje o sprzyjanie Armii Krajowej. Ludzi tych zamordowano w nieznanym miejscu kaźni ${ }^{44}$.

Bezwzględność komunistów, terror i okrucieństwo nowej władzy wobec oficerów i żołnierzy Armii Krajowej i innych ugrupowań niepodległościowych zaczęły się przekładać na poziom dyscypliny w „armii Berlinga”. Pobór do LWP ludności ukraińskiej, byłych żołnierzy AK, nieludzki stosunek oficerów sowieckich i NKWD do poborowych, brak elementarnego wyposażenia osobistego i tworzenie kompanii karnych zaowocowały licznymi dezercjami do lasu. Skala dezercji była tak wielka, że groziła zarzuceniem organizowania niektórych pułków i dywizji 2. Armii LWP ${ }^{45}$. Do końca grudnia 1944 r. zmobilizowano do służby w jednostkach LWP co najmniej 105 tys. ochotników, choć ich liczba mogła być większa ${ }^{46}$. W okrzepłej w bojach 1 . Armii LWP tylko latem 1944 r. zdezerterowało 364 żołnierzy. O wiele gorzej przedstawiała się sytuacja w 1. Korpusie Pancernym i oddziałach 2. Armii LWP. Tylko w październiku 1944 r. z jednostek tej armii zdezerterowało aż 3765 żołnierzy ${ }^{47}$. Pod wpływem pogłosek o spodziewanych aresztowaniach żołnierzy AK w nocy z 12/13 października 1944 r. poszedł $w$ rozsypkę cały 31 pułk piechoty (7 DP) i bynajmniej nie był to efekt agitacji „chłopców z lasu"48. Uciekali do lasu nawet byli partyzanci Armii Ludowej i komunistycznych oddziałów partyzanckich. W połowie w ludowym Wojsku Polskim, „Więź" 1993, nr 7, s. 128.

\footnotetext{
i Podlasie w ogniu 1944-1945. Powiat Sokołów Podlaski. Materiały z sesji naukowej pt. Represje i opór przeciw rządom komunistycznym w powiecie Sokołów Podlaski po 1944 r., red. K. Krajewski, Warszawa 2007, s. 1.

Zob. M. Kisielewski, Raport o zabijaniu, „Zeszyty Historyczne” 1993, nr 106, s. 92 i nast.

J. Pawłowicz, Działalność NKWD na Podlasiu w latach 1944-1945 (zarys problematyki), [w:] Mazowsze
} Zob. I. Sewastianowicz, S. Kulikowski, Nie tylko Katyń, Białystok 1999.

Ludowe Wojsko Polskie w okresie od 1 sierpnia do 31 grudnia 1944 r. powiększyło się o 164 tys. oficerów i żołnierzy i liczyło według stanów żywieniowych w końcu tego roku 275 tys. ludzi. Zob. Polski wkład w zwycięstwo nad Niemcami 1939-1945, WPH, 1975, dodatek nr 1-2, s. 75.

46 Dane statystyczne podaję za: A. Wesołowski, op. cit., s. 222 i nast.

I. Blum, Sprawa 31 putku piechoty. Tło, przebieg i charakter masowej dezercji żotnierzy 31 pp w 1944 r., WPH 1965, nr 3. 
sierpnia 1944 r. zdezerterowało z 8 DP ok. 150 żołnierzy LWP wywodzących się z komunistycznego zgrupowania „Jeszcze Polska nie zginęła” płk. Roberta Satanowskiego. W nocy z 1/2 marca 1945 r. z Oficerskiej Szkoły Pancernej w Chełmie Lubelskim zbiegło "do lasu” 70 podchorążych z dowódcą kompanii na czele, który założył oddział partyzancki i przybrał ps. „Wołyniak”. Tego samego dnia poszedł w rozsypkę 2. batalion 28 pp., zaś 23 kwietnia 1945 r. zdezerterował w Lubaczowie "do lasu” 22. Samodzielny Batalion KBW. Kilka dni później z biłgorajskich koszar zbiegło ok. 500 żołnierzy, z których część zaatakowała nawet w drodze "do lasu” miejscową siedzibę Urzędu Bezpieczeństwa. Grupowe dezercje obejmujące od kilkunastu do kilkudziesięciu oficerów i żołnierzy miały miejsce również w czasie przemarszu oddziałów 1. i 2. Armii LWP na front. Tylko do końca 1945 r. zdezerterowało z LWP ok. 25 tys. żołnierzy, co było faktem starannie skrywanym w okresie Polski Ludowej $^{49}$. Odpowiedzią aparatu bezpieczeństwa i sprzężonego z nim sądownictwa wojskowego było wzmożenie represji i szeroka akcja profilaktyczna. Uprawniony jest pogląd, że liczba żołnierzy oficjalnie skazanych na śmierć przez sądy polowe na mocy wyroków była mniejsza od liczby zamordowanych bez wyroku sądowego.

Nie każdy przypadek dezercji można tłumaczyć wyborami politycznymi i represjami Informacji Wojskowej. Żołnierze wcieleni z polskich Kresów włączonych do ZSRS otrzymywali listy z opisem okrucieństw banderowców. W rezultacie, wielu $\mathrm{z}$ nich dezerterowało $\mathrm{z}$ bronią i powróciło przez nową granicę do domów. $Z$ informacji posiadanych przez szefa Sądu Polowego 10. DP wynikało, że w rejonie Mościsk miejscowy oddział samoobrony tworzyło 120 dezerterów z oddziałów 2. Armii LWP. Co ciekawe, lokalny szef NKWD nie reagował na wnioski o doprowadzenie dezerterów do swoich jednostek ${ }^{50}$. Dezerterzy, których ujęto w drodze do ZSRS, tłumaczący się obawą o życie najbliższych, mogli liczyć na łagodniejsze traktowanie. Dla przykładu, kan. G. otrzymał list $\mathrm{z}$ domu rodzinnego pod Tarnopolem o zbrodniach UPA i zdezerterował z bronią z 39. pal. Ujęty stanął przed sądem i został skazany na karę śmierci. Jednak zwierzchnik sądowokarny biorąc pod uwagę motywy dezercji zamienił karę śmierci na karę 10 lat pozbawienia wolności z odroczeniem jej wykonania do końca wojny i skierowaniem skazanego do oddziału karnego ${ }^{51}$. Innym, nie mniej ważnym powodem dezercji, były tragiczne warunki bytowania żołnierzy w ośrodkach formowania w "Polsce Lubelskiej”. Najpełniejszy opis tych warunków oddaje raport szefa Sądu Polowego 8. DP z 11 października 1944 r.: „(...) żołnierze dłuższy czas nie mieli dachu nad głową, chodzili w cywilnych, letnich ubraniach, wielu z nich boso. Żywili się własnym kosztem

49 H. Piecuch, Spotkania z Fejginem. Zza kulis bezpieki, Warszawa 1990, s. 64.

50

51 CAW - III-127-164, s. 4-6. 
w pobliskich wsiach. Nie dostarczono im wody do mycia. Przez 5 tygodni nie otrzymywali na zmianę czystej bielizny. Większość spędzała noce w lesie pod gołym niebem i siniejąc z zimna nie sypiała. Nie mieli też żadnej opieki lekarskiej. Chorzy, owrzodzeni leżeli w brudnych barłogach..." ${ }^{25}$. Od października 1944 r. prokuratury i sądy polowe 2. Armii LWP obrały twardy kurs. Według badań Andrzeja Wesołowskiego, na każdych 10 tys. oficerów i żołnierzy LWP odsetek represjonowanych przez sądy w okresie od początku sierpnia do końca grudnia 1944 r. wynosił 10,4\%. Z tego, aż 657 żołnierzy skazano za dezercję, 51 - za uchylanie się od obowiązku wojskowego, 14 - za przestępstwa przeciw karności, 34 - za zbrodnie stanu, 55 - za nadużycia władzy ${ }^{53}$. W przypadku dezercji podstawowym środkiem represji karnej była kara śmierci. Co trzeci orzeczony wyrok śmierci był wykonywany, natomiast zwierzchnicy sądowokarni chętnie zamieniali pozostałe wyroki śmierci na kary pozbawienia wolności z odroczeniem ich wykonania do końca wojny, co automatycznie oznaczało skierowanie skazanego do służby w oddziałach karnych. Każda dywizja była budowana od kompanii karnej i drużyny oficerskiej ${ }^{54}$. Początkowo prokuratorzy sprzeciwiali się tej praktyce egzekwowania posłuszeństwa i porządku prawnego w siłach zbrojnych, ale szybko okazało się, że oddziały karne spełniały swoją rolę 5 .

Wojskowy wymiar sprawiedliwości w LWP i „Polsce Lubelskiej” był tylko jednym z wielu instrumentów utrzymania dyscypliny wojskowej i porządku prawnego. Każdy dowódca wojskowy miał bowiem prawo aresztowania swego podwładnego ze względu na potrzeby dyscypliny wojskowej ${ }^{56}$. W kwietniu 1944 r. utworzono Oddział Karny 1. Korpusu PSZ w ZSRR w składzie dwóch kompanii, który był samodzielną jednostką podległą dowódcy Korpusu i nadzorowi prokuratora ${ }^{57}$. W założeniu do Oddziału Karnego kierowano byłych oficerów, podoficerów i żołnierzy, którzy w stopniu szeregowców przez walkę z wrogiem na szczególnie niebezpiecznych odcinkach frontu mieli poprawić się i zrehabilitować za popełnione przestępstwa. Z badań Z. Burdy i A. Czułowskiego wynika, że do kompanii karnych skierowano $74 \%$ skazanych na kary bezwzględnego pozbawienia wolności przez Sąd Polowy 1. Korpusu PSZ i Sąd Polowy 1. DP, natomiast w ostatnim kwartale 1944 r. odsetek skazanych przez sądy polowe 1 . Armii LWP wzrósł do $86 \% 58$. Oddziały Karne z powodzeniem

\footnotetext{
CAW - III-5-553, k 41.

53 A. Wesołowski, op. cit., s. 288, tabela nr 58.

54 J. B. Krzyżanowski, op. cit., s. 223.

55 Zob. sprawozdanie Prokuratora 1. Armii WP za maj 1945 r. - CAW, III-439-68, k. 159.

56 Rozkaz Dowódcy 1. DP z 22.06.1943 r. - CAW, III-7-488, k. 32.

57 Zob. Regulamin Oddziału Karnego z 20.04.1944 r. - CAW, III-4-158, k. 36 i nast.

58 Z. Burda, A. Czułowski, Odroczenie wykonania i darowanie kary w czasie wojny (cz. I), WPP, 1964, nr 1, s. 24-25.
} 
spełniały swoją rolę. Nie trzeba dodawać, że w oddziałach tych, które podczas każdej ofensywy prowadziły rozpoznanie bojem i ponosiły największe straty osobowe pełnili służbę żołnierze uznani za "wrogów ludu”, tj. jawnych i potencjalnych przeciwników komunistycznej władzy. Odziały karne w LWP zostały sformowane na wzór "sztrafbatalionów” w Armii Czerwonej.

$\mathrm{W}$ praktyce sądów polowych $\mathrm{w}$ okresach przerw $\mathrm{w}$ działaniach wojennych systematycznie organizowano pokazowe rozprawy $\mathrm{z}$ udziałem całego składu osobowego pułków i brygad. Dla przykładu, w końcu czerwca 1944 r. odbyła się pokazowa, publiczna rozprawa przed Sądem Polowym 1. Armii LWP kilku kanonierów 5. Brygady Artylerii Ciężkiej za kradzież krowy. Był to okres popełniania kradzieży mienia na szkodę miejscowej ludności, wyzbywania się wyposażenia wojskowego, kradzieży lub zamiany przedmiotów osobistego wyposażenia na alkohol i żywność. Wyrokiem sądu polowego dwóch kanonierów zostało skazanych na karę śmierci, a dwóch na kary więzienia, przy czym, karę śmierci wykonano wobec jednego kanoniera, rozstrzeliwując go przed frontem dywizjonu ${ }^{59}$. W 2. Armii LWP śledztwa prowadzono w języku rosyjskim, a rozprawy pokazowe organizowano przed ważnymi wydarzeniami na froncie w celu podniesienia dyscypliny i porządku wojskowego ${ }^{60}$. Najczęściej egzekucje przeprowadzano z udziałem wojska lub ludności cywilnej. Kapral Czesław Buławski, były żołnierz 28 pp 10. DP, wspomina, że rozstrzeliwanie dezerterów przed frontem oddziału było szokiem dla młodych żołnierzy. „Po egzekucji dokonanej przed frontem pułku za dezercję byliśmy tak wstrząśnięci śmiercią kolegi, że batalion przez dłuższy czas nie mógł złapać równego kroku. Każdy z nas myślał o tym co się stało i na ludzi padł strach. Najgorsze, że do plutonu egzekucyjnego wyznaczano zwykłych żołnierzy spośród nas"61. Opisany przypadek przedstawia rzeczywistość kształtowania dyscypliny wojskowej, a tym samym budowania zdolności bojowej w 28. pp z 10. DP przy pomocy organów wojskowej służby sprawiedliwości. W podobny sposób postępowano w innych pułkach $^{62}$. Z dokumentów wytworzonych przez organy służby sprawiedliwości 2. Armii LWP wynika, że śledztwa trwały 1-3 dni, zaś rozprawy przeprowadzano po upływie kilku tygodni. Taka praktyka została zakwestionowana przez Sąd Polowy 2. Armii LWP w końcu grudnia 1944 r. Wszystkie sądy polowe zostały zobowiązane do pilnego wdrażania postępowań sądowych, zaś

M. Szczurowski, 5. Brygada Artylerii. Tradycje, Historia, Wspótczesność, Warszawa 1998, s. 96.

60 i brygad, wydziałach Informacji Wojskowej i niektórych sądach polowych.

61 Relacja szer. Czesława Buławskiego z 28 pp 10. DP złożona 10 czerwca 2012 r. w Lesznie - zbiory autora.

62 Według oficjalnych statystyk w Armii Czerwonej rozstrzelano w czasie wojny ok. 135 tys. oficerów i żołnierzy nie licząc zastrzelonych bez sądu, których liczbę szacuje się od 300 do 400 tys. Dla porównania w armii USA rozstrzelano na mocy wyroków sądów wojennych ogółem 146 żołnierzy, w armii brytyjskiej - 40, francuskiej - 102 . 
wszelkie tłumaczenia o oddaleniu siedzib sądów od ośrodków formowania były stanowczo odrzucane ${ }^{63}$.

Przestępczość w oddziałach LWP zwiększała się w czasie wolnym od działań bojowych, a wydatnie malała po wejściu oddziałów do akcji bojowej. Podobne zjawisko zauważono w PSZ na Zachodzie. Gwałtowny spadek przestępczości odnotowywano zawsze po rozpoczęciu ofensywy. Było to skutkiem radykalnego ograniczenia kontaktów żołnierzy z ludnością cywilną, zaostrzenia dyscypliny wojskowej i realnego zagrożenia oddania naruszyciela prawa i regulaminów pod sąd polowy działający w trybie przepisów o postępowaniu doraźnym. W pododdziałach 2 . DP po rozpoczęciu ofensywy styczniowej w 1945 r. przestępczość spadła średnio o $80 \%{ }^{64}$. W 2. Dywizji Artylerii sędziowie i prokuratorzy byli w zasadzie bezrobotni. W czasie zaciekłych walk w kwietniu 1945 r. pod Budziszynem w ogóle nie stwierdzono dezercji i innych przestępstw. Prokurator 2. DA meldował przełożonym, że: „żołnierze zachowywali zimną krew i nawet przy wycofywaniu się stali zwarcie przy swoich dowódcach, wykonywali rozkazy i ratowali sprzęt" ${ }^{\prime \prime 5}$. To dość niezwyczajna pochwała ze strony prokuratora. Faktem jest, że artylerzyści w czasie bitwy budziszyńskiej nie zawiedli, czego nie można powiedzieć o dowódcy armii, gen. Świerczewskim, który zupełnie zagubił się w czasie niemieckiej kontrofensywy. Sędziowie i prokuratorzy dywizyjnych sądów polowych 1. i 2. Armii LWP pełnili swoje obowiązki przy sztabach macierzystych jednostek, a nierzadko na pierwszej linii frontu. Co najmniej polowa prawników wojskowych epizodycznie wzięła udział $w$ walkach frontowych. Przykładowo, sędziowie Sądu Polowego 1. Armii LWP w lutym 1945 r. walczyli z bronią w ręku w obronie Jastrowia. W dniu 24 kwietnia 1945 r. podczas operacji berlińskiej poległ zastępca szefa Sądu Polowego 1. Armii LWP ppor. Władysław Michnowski. Dramatyczne były wojenne losy prawników wojskowych 2. Armii LWP pod Budziszynem. W dniach 26-27 kwietnia 1945 r. polegli podczas przebijania się z okrążenia pod Kuckau sędziowie i prokuratorzy Sądu Polowego 9. DP: por. Henryk Maniszewski i ppor. Michał Pędziński, a ciężkie rany odnieśli por. Eugeniusz Chromicki i ppor. Tytus Bohaczek ${ }^{66}$. Sędziowie Sądu Polowego 5. DP przebijali się walcząc na bagnety $\mathrm{w}$ okrążeniu pod Tauer, gdzie zginął dowódca dywizji, gen. Aleksander Waszkiewicz i oficerowie jego sztabu. Prawnicy wojskowi dzielili zatem los sztabów dywizji i armii, w których były usytuowane sądy i prokuratury wojskowe. Sądy i prokuratury 2. Armii LWP, 5. DP, 8. DP, 9. DP i 1. Korpusu Pancernego po sforsowaniu Nysy Łużyc-

63 CAW - Wojskowy Sąd Polowy 7. DP, IX.4.96.267, k. 4.

64 B. Dzięciol, Sąd Polowy 2. Dywizji Piechoty, „Przegląd Wojsk Lądowych” 1985, nr 12, s. 131.

65 CAW - Sąd Polowy 2. Dywizji Artylerii, IX.4.96.299, k. 3.

66 B. Dzięcioł, W 35 rocznicę bohaterskiej śmierci oficerów służby sprawiedliwości, WPP 1980, nr 3, s. $281-282$. 
kiej i w szczytowym okresie bitwy budziszyńskiej znajdowały się przy swoich sztabach. Niektóre sądy polowe, jak np. Sąd Polowy 7. DP, stracił kontakt ze sztabem swego związku taktycznego, co zostało później poddane krytyce. Sąd Polowy 7. DP aż do 22 kwietnia 1945 r. pozostał na prawym brzegu Nysy i po rozerwaniu ugrupowania armii przez niemiecką kontrofensywę do 30 kwietnia 1945 r. nie zdołał dotrzeć do swego sztabu ${ }^{67}$. Na pierwszej linii zawsze funkcjonował dywizyjny Wydział Informacji Wojskowej, który dysponował własnym aresztem i plutonem ochrony ${ }^{68}$.

Reasumując, wojskowy wymiar sprawiedliwości LWP od początku swego istnienia był wprzężony w system podporządkowania całego stanu osobowego oddziałów frontowych komunistycznemu ośrodkowi władzy i sowietyzacji Ludowego Wojska Polskiego. Komuniści sowieccy posiadali własne doświadczenia na polu egzekwowania posłuszeństwa rozkazowi i infiltracji dużych zbiorowości ludzkich, w tym sił zbrojnych. Delegowani do LWP i aparatu bezpieczeństwa oficerowie Armii Czerwonej, SMIERSZ-a i NKWD wprowadzili w dywizjach policyjny terror i dyscyplinę na wzór sowiecki, używając doraźnie przedwojennej symboliki i cynicznego odwoływania się do tradycji II Rzeczypospolitej. Praktyka orzecznicza sądów wojennych była nakierowana na przygotowanie Wojska Polskiego i wyczerpanego wojną społeczeństwa do przyjęcia ideologii komunistycznej i eliminacji z szeregów wojska ludzi nieakceptujących pojałtańskiej rzeczywistości.

\section{Bibliografia}

E. Bandosz, Rozwój wojskowego prawa karnego w latach 1943-1945, „Wojskowy Przegląd Historyczny" $1986 \mathrm{nr} 4$.

V. Birstein, Smiersz - tajna broń Stalina. Sowiecki kontrwywiad wojskowy podczas II wojny światowej, Kraków 2013.

I. Błagowieszczański, Zarys formowania 1 Armii Wojska Polskiego, „Wojskowy Przegląd Historyczny" 1959, nr 1.

I. Blum, Sprawa 31 pułku piechoty. Tło, przebieg i charakter masowej dezercji żotnierzy 31 pułku piechoty w 1944 r., „Wojskowy Przegląd Historyczny” 1965, nr 3.

B. Dzięcioł, Sadownictwo wojenne LWP, „Wojskowy Przegląd Prawniczy” 1978, nr 1.

B. Dzięcioł, Sąd Polowy 1 Korpusu PSZ w ZSRR. Organizacja i działalność (cz. 1), „Wojskowy Przegląd Prawniczy" 1980, nr 1.

B. Dzięcioł, Sąd Polowy 2. Dywizji Piechoty, „Przegląd Wojsk Lądowych” 1985, nr 12.

67 CAW - Wojskowy Sąd Polowy 7. DP, IX.4.96.267, k. 5.

68 CAW - Wojskowy Sąd Polowy 8. DP, IX. 4.96.270, s. 12-13. 
B. Dzięcioł, W 35 rocznicę bohaterskiej śmierci oficerów stużby sprawiedliwości, „Wojskowy Przegląd Prawniczy" 1980, nr 3.

T. Gęsek, Z. Hofman, Pomoc ZSRR dla narodu polskiego w jego walce z Niemcami hitlerowskimi, [w:] 20 lat ludowego Wojska Polskiego, Warszawa 1967.

Cz. Grzelak, H. Stańczyk, S. Zwoliński, Armia Berlinga i Żymierskiego, Warszawa 2002.

S. Guzy, Zapomniana uchwała, „Wojskowy Przegląd Prawniczy” 1963, numer specjalny.

L. Kania, Polskie sady wojskowe w Armii Polskiej gen. Władysława Andersa w ZSRS oraz na Bliskim i Środkowym Wschodzie (1941-1943), "Zeszyty Naukowe UPH w Siedlcach" 2014, nr 100.

L. Kania, Służba sprawiedliwości w Wojsku Polskim 1795-1945. Organizacja, prawo, ludzie, Siedlce 2015.

T. Karpiński, Wydział Zamiejscowy Wojskowego Sądu Polskich Kolei Państwowych w Poznaniu (1947-1949), „Wojskowy Przegląd Prawniczy” 2013, nr 2.

M. Kisielewski, Raport o zabijaniu, „Zeszyty Historyczne” 1993, nr 106.

K. Komorowski (red.), Armia Krajowa. Szkice z dziejów Sił Zbrojnych Polskiego Państwa Podziemnego, Warszawa 2001.

J. B. Krzyżanowski, Kąkolewnica - Podlaski Katyń, „Zeszyty Historyczne”, Paryż, z. 95, 1991.

A. Lityński, O ustanowieniu i upadku tzw. Kodeksu wojskowego Polskich Sił Zbrojnych w ZSRR, „Z dziejów prawa. Prace Naukowe UŚl.”, nr 2455, cz. 8, Katowice 2006.

A. Lityński, Początki prawa komunistycznego w Polsce. Prawo karne wojskowe przed wrześniem 1944 r., „Pamięć i Sprawiedliwość”. Biuletyn Głównej Komisji Badania Zbrodni przeciwko Narodowi Polskiemu, Warszawa 1996.

A. Lityński, Początki służby sprawiedliwości w Polskich Siłach Zbrojnych w ZSRR (1943 r.), [w:] Dawne prawo i myśl prawnicza. Prace historyczno-prawne poświęcone pamięci Wojciecha Marii Bartla, red. J. Malec, W. Uruszczak, Kraków 1995.

A. Lityński, Historia prawa Polski Ludowej, Warszawa 2007.

A. Lityński, Historia prawa radzieckiego 1917-1991. Krótki kurs, „Miscellanea Historico-Iuridica" 2005, t. III.

A. Lityński, Ze studiów nad początkami wojskowego prawa karnego PRL, „Problemy Prawa Karnego", t. 21, red. K. Marszał, Katowice 1995.

A. Lityński, O prawie i sądach początków Polski Ludowej, Białystok 1999.

A. Lityński, Rok 1943 w Polskich Siłach Zbrojnych w ZSRR, [w:] Prace Wydziału Prawa i Administracji UAM, t. 1, Historia prawa - historia kultury. Liber Memorialis Vitoldo Maisel dedicatus, red. E. Borkowska-Bagieńska, H. Olszewski, Poznań 1994.

A. Lityński, Wyrok na "kodeks” PSZ w ZSRR, „Z dziejów prawa. Prace Naukowe UŚl.", nr 2455, cz. 8, Katowice 2006.

M. Muszkat, Podstawowe zasady Kodeksu Karnego Wojska Polskiego, „Wojskowy Przegląd Prawniczy" 1945, nr 1. 
J. Muszyński, Polityczno-prawne aspekty tworzenia Ludowego Wojska Polskiego w latach 1943-1945, „Państwo i Prawo” 1973, nr 10.

J. Muszyński, Jeszcze raz w sprawie kodeksu wojskowego Polskich Sił Zbrojnych w ZSRR z 1943 r. i kodeksu karnego wojskowego z dnia 30 maja 1944 r., "Wojskowy Przegląd Prawniczy" 1965, nr 3.

E. Nalepa, Oficerowie Armii Radzieckiej w Wojsku Polskim, Warszawa 1995.

E. Pawłowski, Ludowe Wojsko Polskie w końcowym okresie II wojny światowej, „,Wojskowy Przegląd Historyczny" 1987, nr 2.

E. Pawłowski, Działalność Najwyższego Sądu Wojskowego w 1945 roku, „Wojskowy Przegląd Prawniczy" 1977, nr 1.

J. Pawłowicz, Działalność NKWD na Podlasiu w latach 1944-1945 (zarys problematyki), [w:] Mazowsze i Podlasie w ogniu 1944-1945. Powiat Sokołów Podlaski. Materiały z sesji naukowej pt. Represje i opór przeciw rządom komunistycznym w powiecie Sokołów Podlaski po 1944 r., red. K. Krajewski, Warszawa 2007.

H. Piecuch, Spotkania z Fejginem. Zza kulis bezpieki, Warszawa 1990.

J. Poksiński, Obóz w Skrobowie w dokumentach (1946-1945), Dokumenty i Materiały. Archiwum Polski Podziemnej 1939-1956, nr 2, 1994.

J. Poksiński, Żotnierze Armii Krajowej w ludowym Wojsku Polskim, „Więź”, 1993, nr 7.

E. Romanowska, Wojskowe prokuratury Polskich Kolei Państwowych w latach 1944-1989. Formalno-prawne podstawy działalności, „Przegląd Historyczno-Wojskowy” 2011, nr 1.

I. Sewastianowicz,, S. Kulikowski, Nie tylko Katyń, Białystok 1999.

W. Sieracki, Rozwój wojskowego prawa karnego (materialnego) w latach 1943-1963, „Wojskowy Przegląd Prawniczy" 1963.

Z. Skoczek, Organizacja pracy w sadach i prokuraturach wojskowych, „Wojskowy Przegląd Prawniczy" 1948, nr 1-2.

M. Szczurowski, 5. Brygada Artylerii. Tradycje, Historia, Współczesność, Warszawa 1998.

K. Szwagrzyk, Zbrodnie w majestacie prawa 1944-1955, Warszawa 2000.

A. Tarnowski, Geneza nowego polskiego ustawodawstwa wojskowego, „Wojskowy Przegląd Prawniczy" 1945, nr 1.

A. Wesołowski, W cieniu wojny i polityki. Sądownictwo Wojska Polskiego na froncie wschodnim w latach 1943-1945, Torun 2003.

M. Zaborski, Ustrój sądów wojskowych w Polsce w latach 1944-1955, Lublin 2005. 